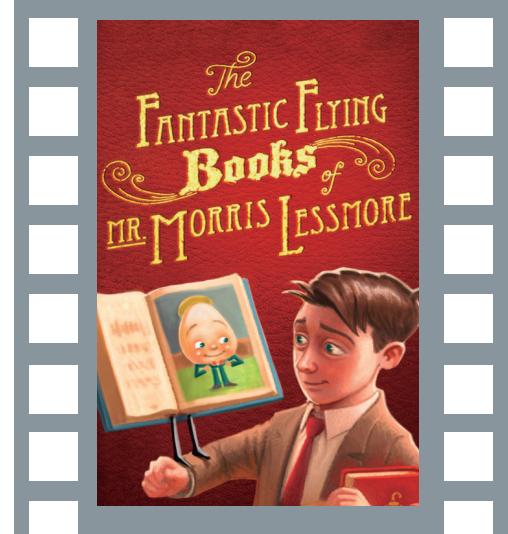

\section{ficha têcnica}

Título original: The Fantastic Flying Books of Mr. Morris Lessmore Nacionalidad: Estados Unidos

Dirección: William Joyce, Brandon Oldenburg

Guión: William Joyce

Productora: Alissa M. Kantrow, Lampton Enochs y Trish Farnsworth-Smith Año: 2011

Distribución: Moonbot Studios

Música: John Hunter

Montaje: Eva Contis

Efectos especiales: Brandon Oldenburg

Género: Cortometraje de Animación

Duración: 16 minutos

Premios: 2012, Oscar al Mejor cortometraje de animación; Seattle International Film Festival al Mejor cortometraje; Cleveland International Film Festival al Mejor cortometraje de animación; Cinequest Film Fest. Premio al Mejor corto animado; Florida Film Festival. Premio de la Audiencia; Palm Springs International Short Fest, Premio del Público. Premio Favorita del público SIGGRAPH.

Web de la productora: http://moonbotstudios.com/

\title{
Los fantásticos libros voladores del Sr. Morris Lessmore
}

"Siempre he creído que la imaginación y la fantasía son muy importantes puesto que forman parte indisoluble de la realidad de nuestra vida" Ana María Matute

María Celina González González

y Carmen Pereira Domínguez

maria.celinagonzalez@edu.xunta.es y mcdguez@uvigo.es

\section{La historia}

El Sr. Morris Lessmore, el protagonista, vivía en Nueva Orleans, rodeado de libros. Un día, mientras escribía su historia en el balcón de un hotel, es trasladado por un fuerte huracán a un lugar desolado, lejos de su ciudad. Entretanto caminaba cabizbajo y desorientado, con la mente en blanco y sin ánimo para escribir, miró hacia arriba y descubrió a una joven guiada por un conjunto de libros que volaban inmersos en un ambiente lleno de color y alegría. Morris deseaba que a su libro le ocurriese lo mismo.

Uno de los libros se acercó al Sr. Lessmore e invitó a seguirle. Llegaron a una casa repleta de libros en la que podría saciar sus ansias de leer y escribir con gran imaginación. Allí permaneció este personaje hasta el final de sus días disfrutando y recreándose de un mundo colmado de vivencias inolvidables.

\section{Temas}

Desarrollo personal

Educación artística

Educación emocional

Educación permanente

El oficio de escribir

Expresión corporal

Fomento y gozo por la lectura

Lectura y escritura

Libros y literatura

Comunicación verbal y no verbal

\section{Valores}

Afectividad
Amistad
Asertividad
Creatividad
Empatía
Esfuerzo
Esperanza
Imaginación
Solidaridad
Superación

\section{(r.) Antes de ver la película}

1. Investigamos sobre los orígenes de las tormentas, huracanes, ciclones, tornados... Buscamos escenas y documentales en YouTube y comentarios sobre sus efectos destructores. Los localizamos en el mapa.

2. Nos centramos en la ciudad estadounidense de Nueva Orleans (historia, geografía, gobierno, cultura, educación...), en los desastres y consecuencias ocasionados por el devastador huracán Katrina, en agosto del año 2005, y en su reconstrucción.

3. Dialogamos sobre nuestros libros de lectura favorita. Sobre el tipo de literatura preferida. Sobre sus artífices e ilustradores. Sobre el libro que estamos leyendo en este momento y cómo ha llegado a nuestras manos.

4. Nos informamos sobre la historia del libro: orígenes, evolución, impresión, imprenta manual, imprenta mecánica, libro del siglo XXI https://es.wikipedia.org/wiki/Historia_del_libro.

5. Nos recreamos con una relación de bibliotecas consideradas las más bellas del mundo: https://www.youtube.com/ watch?v=pkhQMssGggl. Hacemos lo mismo con las librerías más reconocidas del planeta: https://www.youtube.com/ watch?v=TD94KEJ6mSI. Asimismo, con los lugares de encuentro de escritores más famosos: http://www.forumdelcafe.com/pdf/F-35 Diez_caf\%C3\%A9s_literarios.pdf. Y también buscamos en la red museos, fundaciones o casas museo de escritores célebres.

6. Nos informamos sobre las ferias del libro más importantes: http://vos.lavoz.com.ar/listas/las-10-ferias-del-libro-mas-importantes-del-mundo. Sobre los premios literarios más destacados: http://www.lecturalia.com/portada/premios-literarios. Sobre la celebración del Día del Libro: https://www.diadellibro.eu/.

7. Os ofrecemos los siguientes enlaces referentes a los comienzos del cine http://www.uhu.es/cine.educacion/cineyeducacion/comienzoscine.htm; y a los precursores del cine cómico mudo, en especial, Buster Keaton, Harold Lloyd y Charles Chaplin http:// www.adivinaquienvienealcine.com/2011/10/comicos-del-cinemudo.html. Comparamos y comentamos su evolución hasta la actualidad.

8. Para comprender el corto que veremos a continuación, os invitamos a que consultéis y reflexionéis sobre este enlace donde se trata el cine de animación, http://www.uhu.es/cine.educacion/ cineyeducacion/historiacineanimacion.htm.

https://www.youtube.com/watch?v=_Bp1AZthZeo 


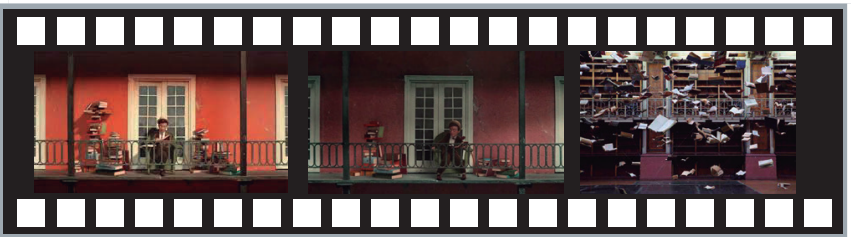

1.1. El corto se inicia con unas imágenes de libros, en el centro, está la obra del Sr. Morris. Observamos cómo pasan las hojas del libro y a protagonista que está leyendo y escribiendo su historia en el balcón de un hotel de la ciudad de Nueva Orleans rodeado de libros en un ambiente tranquilo, armónico y lleno de color. Pero algo extraño está sucediendo (00:30).

tons

1.1. ¿Cómo es la música que escuchamos? Describimos las imágenes y retratamos al Sr. Morris Lessmore, ¿cómo es su aspecto y su vestimenta?, ¿a quién nos recuerda?, ¿qué elementos lo identifican?, ¿cómo es su estado de ánimo?, ¿qué hace día a día?, ¿qué siente por los libros?, ¿qué dibujo vemos en el libro y qué simboliza? Ante la llegada del huracán las escenas empiezan a cambiar. ¿Qué acciones pasan?, ¿cómo son ahora las imágenes?, ¿y la música? Expresamos nuestros sentimientos ante este escenario.

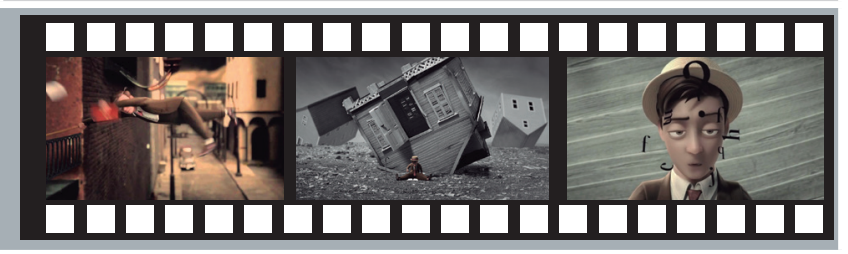

2.1. La dimensión del huracán hace estragos y el Sr. Morris Lessmore logra sobrevivir a las fuertes sacudidas producidas por el intenso viento. Las letras y dibujos de su libro se despegan, vuelan y se dispersan; los postes de la luz se arrancan; las farolas se caen; las ventanas se desprenden; las casas se desploman, todo vuela y todo queda revuelto. Nuestro protagonista aterriza en un lugar inhóspito, está aturdido y desolado. El amaba las palabras, las historias, los libros. Le apasionaba escribir. Pero cuando camina sin rumbo, cabizbajo y triste, algo inesperado va a suceder (03:15).

2.1. Precisamos cómo son las imágenes que vemos ahora. ¿Qué color predomina? ¿Cómo es la música? Describimos los efectos sonoros. ¿Cómo se muestra el Sr. Morris? ¿Qué objetos le acompañan? ¿Qué le ha ocurrido a su libro? ¿Qué sentimientos le invaden? ¿Con qué personas y elementos se encuentra en su camino? ¿Qué percibe para que eleve la mirada y qué acontecimiento lo sorprende? ¿Qué sentido tiene el paso de imágenes en blanco y negro a color? ¿Cómo es el estado de ánimo de Morris?

(3) Su nuevo destino

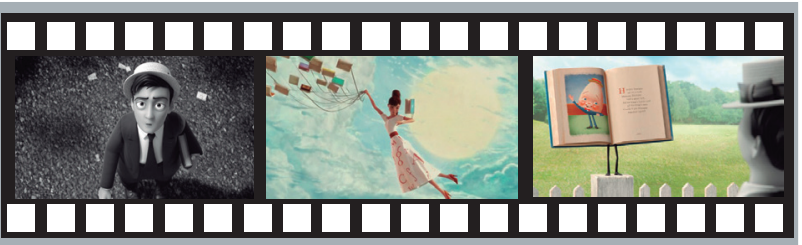

3.1. La chica joven que es trasportada por un grupo de libros voladores comprende la añoranza y tristeza de Morris y, para darle apoyo, se detiene en el aire y le regala el libro amistoso que le acompaña y atesora su historia favorita. Con alegría éste lo saluda y le invita a que lo siga. Juntos llegarán a una gran casa donde albergan cantidad de libros (03:54).

3.1. Contrastamos estas imágenes. ¿Qué simboliza esa joven, qué aspecto tiene y cómo se muestra Morris? ¿Qué intenta y desea el protagonista con su libro y qué cara pone? Nos fijamos en el libro que le ofrece la chica. Nos enteramos de la figura de Humpty Dumpty que aparece en el libro amistoso. ¿Qué relación establece con Morris y qué le sugiere? ¿Hacia dónde creéis que se dirigen? Detallamos estas imágenes, la música y sonidos especiales. ¿Qué significa ese lugar para el protagonista y cómo se expresa? ¿Qué se esconde tras ese grandioso edificio rodeado de naturaleza?

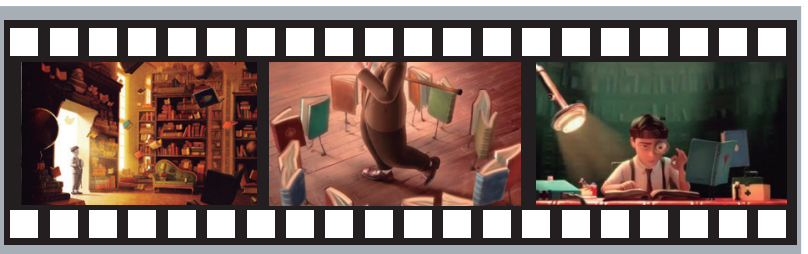

4.1. Desde la entrada del edificio Morris observa con curiosidad a la gran familia de libros que transitan, vuelan y se alojan en las abundantes estanterías. Asombrado y sigiloso los saluda con respeto mientras su amigo le anima a acceder hasta una sala donde está tocando una partitura en un piano. Morris y los libros bailan en círculo al son de la música y al terminar todos aplauden llenos de júbilo. Gracias al libro amistoso Morris volverá a descubrir el gusto por la lectura y la escritura. Los leerá y cuidará mientras viva en la biblioteca. Como así vimos que hizo con el libro, De la Tierra a la Luna, de Julio Verne (05:09).

4.1. Analizamos la entrada de la casa. ¿Qué creéis que pensó y sintió Morris al llegar? ¿A quién ve en uno de los cuadros de la pared? ¿Comentad la impresión que os causa la altura y la disposición de los libros? ¿Cómo es el cuidado, mimo y preocupación del Sr. Morris hacia los libros? Describimos sus variados sentimientos cuando se sumerge en la lectura de tantos libros ¿Y cómo os sentís vosotros? ¿Qué tipos de libros conocéis? Comentamos la música, las imágenes, los sonidos, el ritmo y observamos las ilustraciones de la espiral y la comparamos con la espiral del huracán, ¿qué nos dice una y otra?, iqué diferencias encontramos en ellas? 


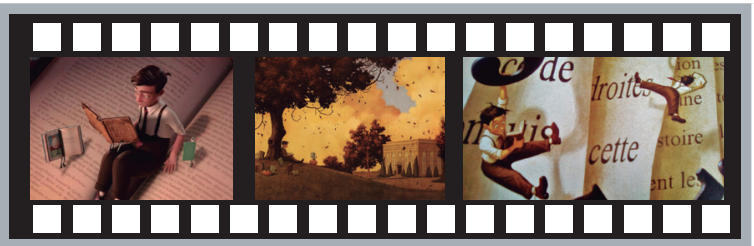

5.1. Algunas veces, el Sr. Morris Lessmore se concentra en la lectura de un libro y no sale de casa, y otras veces se sienta bajo un árbol a leer mientras los libros salen y se recrean volando. Además, comparte y disfruta los libros con todo el vecindario. Y al final del día coge su libro y pluma para escribir sus alegrías, tristezas, deseos... Durante meses, años y hasta el final de su vida (09:45).
5.1. ¿Qué decide retomar el protagonista? ¿En qué espacios está ubicada ahora la escena? ¿Cómo actúan los libros voladores? ¿Cómo es su nueva función de bibliotecario, su plan de vida y de trabajo diario? ¿Cómo es su relación con los vecinos? ¿Qué momentos recoge en su libro? ¿Cómo se percibe el paso del tiempo? ¿En dónde y en qué? ¿Cómo influye el libro amistoso en la vida del Sr. Lessmore?

\section{La despedida}

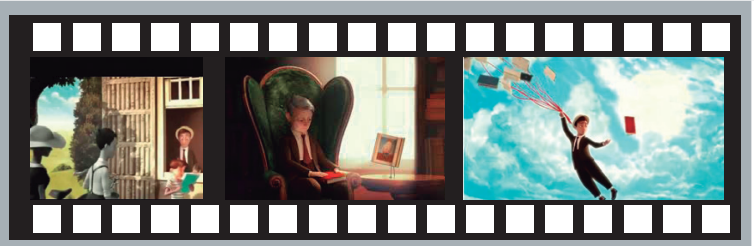

6.1. Y llegó el día en que el Sr. Morris terminó su último dibujo y escribió Fin en la última hoja de su texto. Mientras el libro amistoso lo observa, Morris se levanta de su sofá con su obra bajo el brazo, coge el sombrero y el bastón, camina a paso lento y con ternura se despide de sus libros con su mano en el corazón; éstos lo rodean y elevan y él deja caer su libro. Una niña visita la biblioteca y el libro de Morris la recibe con agrado (11:17).
6.1. ¿Cómo es la despedida? ¿Qué observa? ¿Cómo es la música? ¿Qué hacen ahora sus queridos libros a los que tanto cuidó? ¿Cómo se sienten? ¿Qué permanece para siempre en la biblioteca? ¿A quién se rinde homenaje? ¿Cómo empieza y termina este cortometraje? ¿Cómo valoráis esta historia? ¿Le pondríais otro final?

\section{Alęunas curiosidades de interês}

1. William Edward Joyce, nació en Luisiana, en Estados Unidos, en el año 1957. Es escritor, ilustrador y director de cine y televisión.

2. Entre sus obras literarias, mayoritariamente dirigidas a los más jóvenes, destacan: Los Guardianes de la infancia: Sandy, El Creador de Sueños; HL: El Hombre de la Luna; Toothiana: El Hada de los Dientes; Bunny: Conejo de Pascua; Sombra: El coco (pesadiIlas); Los fantásticos libros voladores de Mr. Morris Lessmore.

3. La Revista Newsweek lo ha considerado una de las 100 personas favoritas del nuevo milenio. Sus ilustraciones han aparecido en numerosas cubiertas de The New Yorkery sus pinturas se exponen en museos y galerías de arte.

4. Como director de cine comenzó su carrera siendo miembro cofundador de Reel FX Creative Studios, desde 1995 hasta 2009, combinando el diseño y los efectos especiales para cine y televisión. También trabajó en empresas como Troublemaker Studios, Pixar, Disney, DreamWorks Animation y Blue Sky Studios.

5. Le apasiona el cine de animación: esbozó los personajes de Toy Story (J. Lasseter, EE.UU.,1995) y de Bichos (J. Lasseter y A. Stan- ton, EE.UU. 1998); ha producido Robots (C. Wedge y C. Saldanha. EE.UU., 2005); y Epic (C. Wedge, EE.UU., 2013) está basada en su obra, Los guardianes de la infancia.

6. Cuando trabajaba en DreamWorks Animation colaboró en El origen de los Guardianes (2012) y se la dedicó a su hija Katherine, fallecida a los 18 años de un tumor cerebral, en el 2010.

7. En agosto de 2009, William Joyce y Brandon Oldenburg fundaron la compañía de animación, Moonbot Studios, y crearon el cortometraje Los fantásticos libros voladores del Sr. Morris Lessmore, (2011), inspirado en el filme, El mago de Oz (V. Fleming, EE.UU., 1939), en la experiencia real del huracán Katrina y en el cine mudo de Harold Lloyd y Buster Keaton. Además, combina una variedad de técnicas: miniaturas, animación por ordenador y animación 2D, presentando un estilo que se remonta a las películas mudas y musicales de Metro-Goldwyn-Mayer en Technicolor.

8. Este corto retoma el personaje de Humpty Dumpty, el huevo personificado y su don especial para comunicarse con el protagonista https://es.wikipedia.org/wiki/Humpty_Dumpty. 
1. Una vez visto el cortometraje, formulamos las siguientes cuestiones: reflexionamos sobre su título. ¿Qué creéis que nos quiere contar esta historia? ¿Qué ambientes y lugares aparecen? ¿Qué tipos de personajes se presentan? ¿Qué es lo que más os ha gustado? ¿Y lo que menos? ¿Qué cambiaríais? Buscamos en la red críticas cinematográficas de personas expertas y las debatimos.

2. Pensamos sobre la frase del escritor Agustín Fernández Paz, "Todas las historias se tejen con los hilos de la vida" y la relacionamos con este corto de animación.

3. Hablamos de las bibliotecas, su ubicación y tipos (de aula, de centro, municipales, institucionales, nacionales, etc.). ¿Cómo son las personas que trabajan en ellas? Nos fijamos en su arquitectura exterior y estructura interna, la clasificación y colocación y de los libros, el reglamento y las normas de acceso y uso...

4. Preparamos y llevamos a cabo una salida a la biblioteca municipal para conocer su funcionamiento y entrevistamos al personal que allí trabaja. Elaboramos gráficos de los libros más leídos, de las colecciones más demandadas, del género de los libros más solicitados, de las obras premiadas, de los libros incunables...

5. Realizamos una mesa redonda con defensores y detractores de la literatura y debatimos qué sucedería si los libros desapareciesen 0 si dejásemos de leer. ¿Y si los reemplazamos por tablets, e-books, etc.? ¿Qué pasaría con los escritores, editoriales, librerías, bibliotecas? Comparamos los libros ilustrados con los libros electrónicos y exponemos las semejanzas y diferencias, ventajas e inconvenientes.

6. Pedimos a nuestras familias que nos cuenten qué libros nos leyeron en nuestra infancia y cómo, cuándo y dónde lo hacían. ¿Guardamos en nuestros hogares algunos de estos cuentos? Si es así, los llevamos al aula e intercambiamos estas experiencias.

7. Elaboramos carteles para colocar en el centro educativo, recreativo, sociocultural... del lugar donde vivamos para realizar actividades cooperativas de fomento de la lectura, creación de textos literarios, talleres de escritura, cuentacuentos, etc.

8. Grabamos un vídeo a partir de una historia original e inédita en dibujo animado cuyo objetivo sea favorecer la lectura entre el alumnado y luego lo colgamos en la web o blog del centro educativo.
9. Invitamos a un autor o autora de un libro de literatura infantil o juvenil que acuda al centro educativo y organizamos una tertulia para que nos cuente sus vivencias personales y profesionales con el mundo literario, nos presente y hable de sus libros, nos haga bocetos de sus ilustraciones... Y con este aprendizaje nos aventuramos a crear nuestro propio libro de misterio, de intriga, de aventuras.

10. Leemos un libro que nos agrade y después organizamos un plan para que éste siga volando. Lo dejamos en lugares estratégicos, con pistas para encontrarlo, y le adjuntamos en su interior un mensaje que anime a que lo sigan leyendo y así se amplíe el círculo de lectores. Reflexionamos sobre esta fantástica aventura.

11. Escenificamos representaciones mímicas de gestos o acciones intentando que nos entiendan las personas y podamos comunicarnos. Contamos con el apoyo de algún miembro de la Once o de la Asociación de Sordos para que nos cuenten sus vivencias y nos enseñen su forma de expresarse con los demás por medio del braille y el lenguaje de signos.

12. Exponemos nuestras valoraciones sobre los libros que hayamos leído y que también fueron adaptados al cine. ¿Los hemos leído antes 0 después de ver la película? ¿Qué preferimos literatura 0 cine? ¿Qué diferencias y semejanzas encontramos? ¿Y qué ventajas e inconvenientes tienen? Los fantásticos libros voladores del Sr. Morris Lessmore, es un cortometraje de animación, sin expresión oral que se acompaña de música y efectos sonoros. Originariamente surgió el corto y posteriormente, en el 2014, se publicó el cuento, con el mismo título, pero con imágenes y texto. William Joyce también dedicó ambos trabajos a la memoria de su hija Katherine. http://www.tinglado.net/?id=los-fantasticoslibros-voladores

http://onceuponafaeriebook.blogspot.com.es/2016/08/foto-resena-los-fantasticos-libros.html

13. Finalmente, os ofrecemos este enlace con una sugerente relación de cortometrajes que ayudan a fomentar la lectura y la educación en valores:

http://rz100arte.com/50-cortos-geniales-trabajar-valores-vuestrsalumnos/
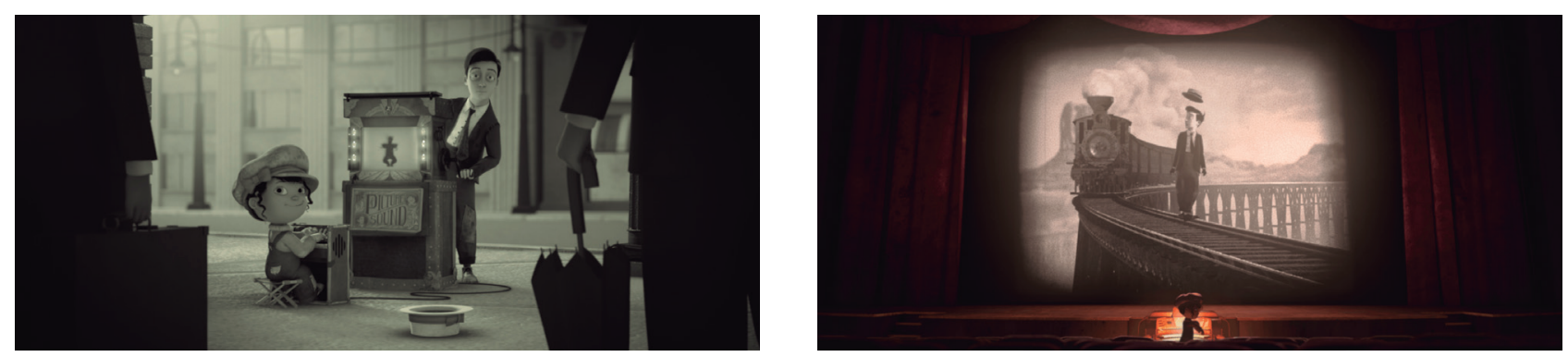

Imágenes extraídas de http://moonbotstudios.com/ 